\title{
The Impact of Golf Courses on Stream Water Temperature
}

\author{
Weston Dripps ${ }^{1, *}$, Kevin Ashman ${ }^{2}$, Megan Saunders ${ }^{3}$ and Summer Drake ${ }^{4}$ \\ ${ }^{1}$ Department of Earth and Environmental Sciences, Furman University, Greenville, SC 29613, USA \\ ${ }^{2}$ Department of Geology and Geography, Georgia Southern University, Statesboro, GA 30458, USA \\ ${ }^{3}$ PO Box 1341, Hood River, OR 97031, USA \\ ${ }^{4}$ Department of Biology, DePauw University, Greencastle, IN 46135, USA
}

\begin{abstract}
Golf courses are an increasingly prominent feature across the urban landscape. Most courses contain streams that pass through the course grounds and have the potential to chemically, biologically, and physically alter these streams and their aquatic ecosystems. This study assessed the impact of five golf courses in Greenville, South Carolina on stream water temperature. Courses were selected that had continuous, tributary and lake free reaches that passed through the golf course grounds. At each course, stream water temperature was measured at 5 minute intervals from July - October 2008 just upstream and downstream of the course. Under baseflow conditions during the period of record, the sites downstream of the courses exhibited (1) elevated stream water temperatures (on the order of $3-4{ }^{\circ} \mathrm{C}$ during the afternoon hours) and (2) increased diurnal temperature ranges $\left(1-4{ }^{\circ} \mathrm{C}\right.$ larger) compared to their upstream counterparts. The observed temperature differences between the upstream and downstream sites at each course were primarily due to the lack of riparian cover along the golf course reaches. The magnitude of the temperature differences among the courses was largely a function of stream discharge. Although the impacts of these temperature modifications on the ecology, biology, and chemistry of the stream system were not assessed, the changes are large enough to be of ecological concern. New golf course guidelines that recommend or require the retention of sizable vegetated buffers along stream banks that shade the streams may be necessary to help protect the health of these aquatic ecosystems.
\end{abstract}

Keywords: Diurnal variability, golf course, riparian cover, stream, water temperature.

\section{INTRODUCTION}

Golf courses have become a prominent feature within urban and rural landscapes, with an estimated 35,000 courses globally [1], about half of which are located in the United States. Most golf courses incorporate one or more streams into their layout, typically for aesthetics, as a water hazard, and/or as a source of irrigation water for the turf. These courses, depending on their design and management, have the potential to negatively impact streams and their aquatic ecosystems, chemically, biologically, and physically.

Common golf course practices or design features that could alter a stream's aquatic ecosystem include the entry of pesticides and fertilizers into the stream via runoff or groundwater flow, reconfiguration and channelization of streams, increased erosion and stream turbidity, particularly during the construction phase of the course, and removal and/or cutting of vegetated buffers along the stream banks. Previous books [2-4] have highlighted the need to protect the aquatic environment from golf course development and operation. Many previous studies [5-18] have documented changes and impacts that golf courses have had on stream

*Address correspondence to this author at the Weston Dripps, Furman University, Department of Earth and Environmental Sciences, 3300 Poinsett Hwy, Greenville, SC 29613; Tel: (864) 294-3392, Fax: (864) 294-3585; E-mail: weston.dripps@furman.edu, water chemistry, but relatively little research has looked at the impacts courses are having on physical water quality parameters like stream water temperature.

Stream water temperature is an extremely important water quality parameter and significantly impacts the health of stream ecosystems. It not only influences the biological functioning of a stream including the survival, reproduction, physiology, and metabolic rates of many aquatic species, but also governs many important physical and chemical water quality characteristics and processes, including chemical reaction rates, chemical toxicity, microbial activity and productivity, and the solubility of gases like oxygen [19-21]. Most aquatic organisms have a specific range of temperatures they prefer, and are very susceptible to changes and fluctuations in water temperature [20]. Permanent shifts in the stream temperature can render formerly suitable aquatic habitats unsuitable for native species [22].

Golf courses can impact stream water temperature through a number of mechanisms including reductions in base flow (from direct pumping or lowering of the water table due to ground or surface water withdrawals for turf irrigation), changes to the natural flow regime associated with channel reconfiguration and/or the addition of ponds and water features, and the reduction in shading of streams due to the removal and cutting of the vegetated buffers along stream banks. 
Table 1. Discharge Measurements Made Under Baseflow Conditions in August 2008 and the Measured Length of Stream Reach Within Each Course

\begin{tabular}{|c|c|c|c|c|c|}
\hline Golf Course & GC 1 & GC 2 & GC 3 & GC 4 & GC 5 \\
\hline \hline Discharge $\left(\mathrm{m}^{3} / \mathrm{sec}\right)$ & 0.014 & 0.012 & 0.018 & 0.213 & 0.004 \\
\hline Length of Course Reach $(\mathrm{m})$ & 713 & 1618 & 893 & 1212 & 454 \\
\hline
\end{tabular}

With the large number of golf courses already in use and the continued development of golf courses globally, assessing and quantifying the impacts golf courses are having on stream temperatures is critical for documenting the magnitude of these changes and helping to develop strategies and guidelines that will protect the health of the stream. The purpose of this study was to assess the impact of five different golf courses in Greenville, South Carolina on the stream water temperature.

\section{MATERIALS AND METHODS}

Five golf courses in Greenville County, South Carolina were selected that had continuous, tributary free, lake free reaches that passed directly through the golf course. The names of the courses will not be revealed in this paper to protect their anonymity, but they are all 18 hole courses within twenty miles of downtown Greenville, South Carolina, which is located in the northwest corner of the state.

Temperature loggers (HOBO Water Temp Pro V2 Data $\operatorname{loggers}{ }^{1}$ ), which measure water temperature at a predetermined frequency, were installed in the stream where the stream enters the golf course and where it exits the golf course. The loggers have an accuracy of $\pm 0.2^{\circ} \mathrm{C}$ from $0^{\circ}$ to $50^{\circ} \mathrm{C}$ and a resolution of $0.02^{\circ} \mathrm{C}$ at $25^{\circ} \mathrm{C}$. Sensors were secured in the stream water column using zip ties attached to cinder blocks or a piece of rebar driven into the stream bottom. Conscious efforts were made to locate the upstream and downstream sensors in similar flow regimes (riffles with similar water depth and flow velocity), similar sandy substrates, and similar shade characteristics to help ensure that any observed differences in the upstream and downstream temperature readings were due to the influence of the golf course reach and not local logger placement.

Stream water temperature was measured at 5 minute intervals from July 1 through October 31,2008 , and the data were offloaded monthly. In addition to stream temperature, stream discharge was manually measured using a current meter under baseflow conditions at the downstream logger location in August 2008, and the length of the golf course reach between the upstream and downstream loggers was determined from topographic maps and aerial photographs (Table 1). A visual assessment of the extent of riparian cover along the stream banks and any human alterations (e.g., channel reconfiguration, rip-rap) to the stream's channel morphology along the golf course reach were also noted.

\section{RESULTS}

The water temperatures up and downstream of each course exhibited a diurnal periodicity (Fig. 1). During a typi-

${ }^{1}$ Manufactured by Onset Computer Corporation, 470 MacArthur Blvd., Bourne, MA 02532 cal day in the summer and fall, water temperatures peaked mid-afternoon (1:30 - 4 PM) and troughed in the early morning hours $(5: 30-7 \mathrm{AM})$, with the timing of the highs and lows more or less synchronous between the upstream and downstream sites (Fig. 1). Seasonally, the average daily water temperatures were higher during the summer months (July and August) and gradually diminished into the fall (September and October) (Fig. 1).

The magnitude of the temperature difference between the downstream and upstream sites varied among the courses (Figs. 2 and 3). The data are plotted absolutely to show the magnitude of the differences (Figs. 2A and 3A), but also as a function of stream length to allow for more comparable comparisons (Figs. 2B and 3B). Stream discharge varied among the courses (Table 1) and was inversely related to the observed temperature differences (Fig. 4). GC 4 which had the largest discharge had the smallest observed temperature change per length of golf course reach while GC 5 which had the smallest discharge had the largest observed temperature change per length of golf course reach. GC 1,2, and 3 which had fairly comparable discharge had similar observed temperature differences, at least for July, August, and September (Fig. 2B).

The size of the temperature difference between the downstream and upstream sites varied temporally at each site on both a monthly and diurnal basis (Figs. 2 and 3). The downstream water temperatures were consistently warmer than the upstream temperatures, except during the late evening and early morning hours. The magnitude of the temperature differences (downstream temperature - upstream temperature) exhibited a diurnal periodicity, reaching a maximum during the mid-afternoon hours and a minimum during the evening and early morning hours (Fig. 3). On a monthly basis, the average temperatures were warmer downstream than upstream except in October at GC 1 and GC 4 where they were slightly cooler (Fig. 2). The size of the average difference diminished from July through October at all five sites (Fig. 2).

In addition to the changes in temperature, differences in the diurnal temperature variability were also observed between the downstream and upstream sites (Fig. 5). The downstream sites had a larger average diurnal temperature range compared to the upstream sites at all five courses for every month monitored. In general, the magnitude of the water temperature diurnal variability diminished from summer to fall, but the trend and magnitude of the differences in the variability between the downstream and upstream sites was not consistent among courses. At GC 3, 4, and 5 the size of the difference in the variability between the downstream and upstream sites progressively diminished from July to October, but at GC 1 it progressively increased and at GC 2 it wavered. 

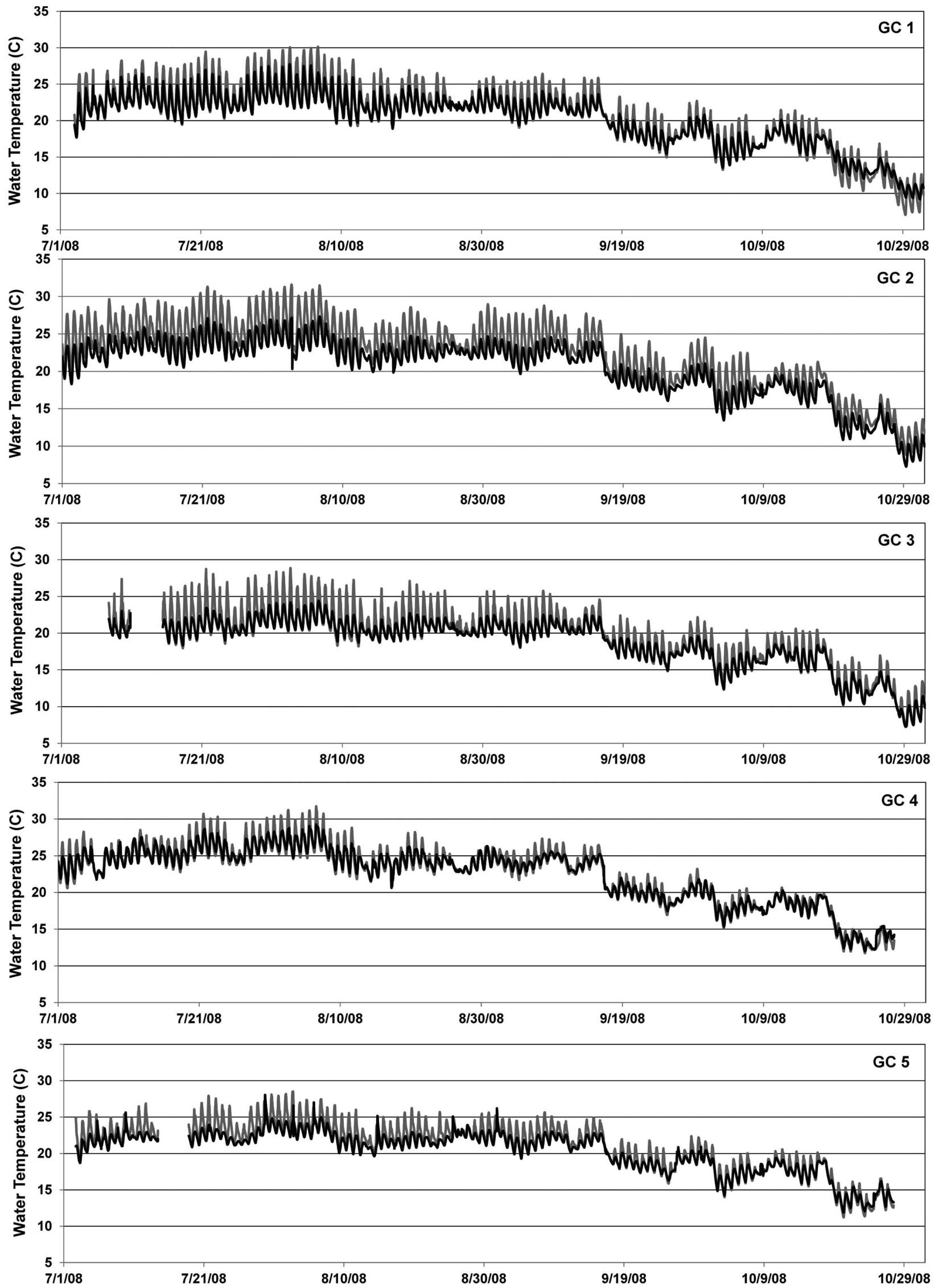

Fig. (1). Stream water temperatures just upstream (black line) and downstream (grey line) of each golf course. 

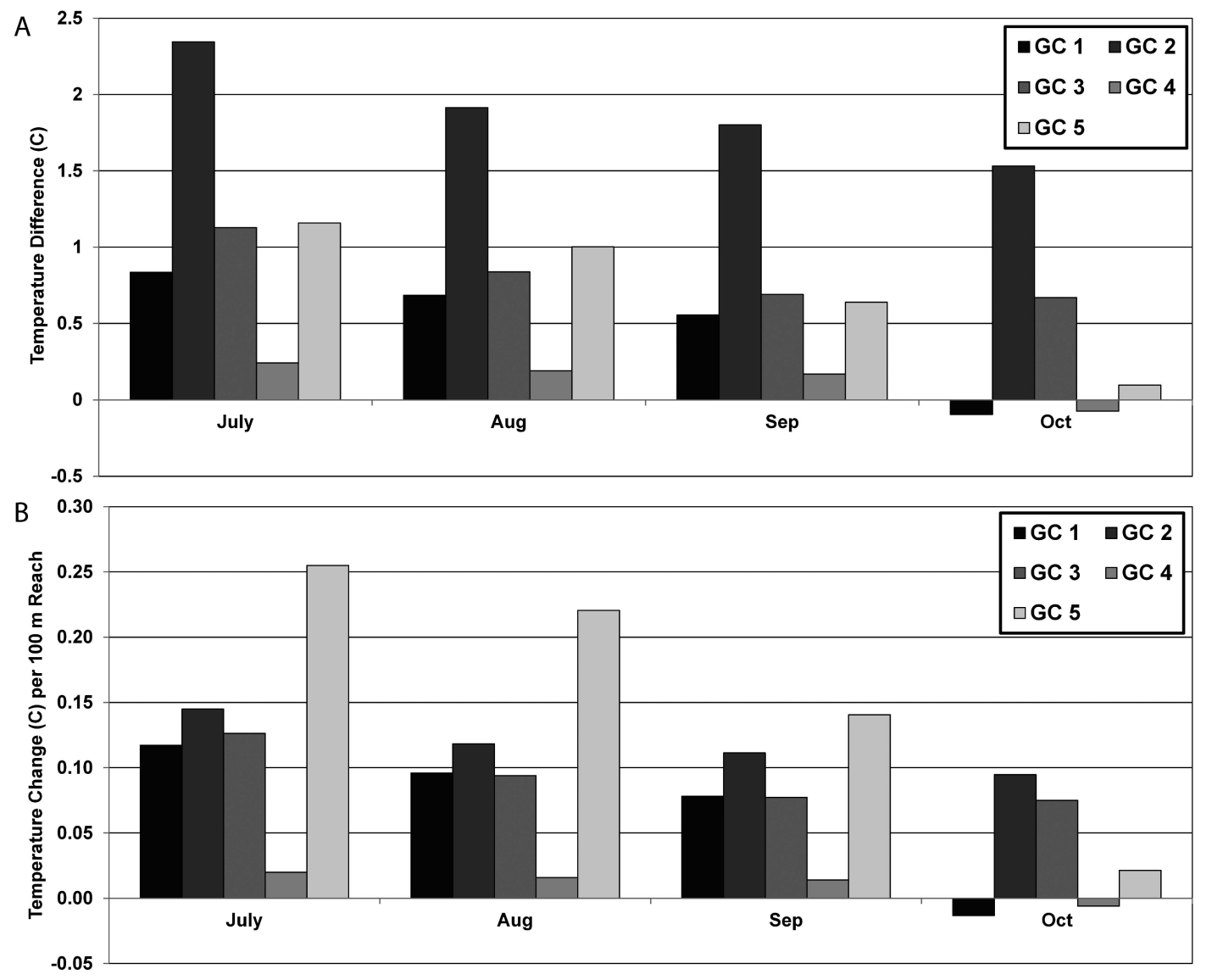

Fig. (2). A) Average water temperature difference between the downstream and upstream monitoring locations. B) Average water temperature difference per 100 meters of golf course reach between the downstream and upstream monitoring locations.

\section{DISCUSSION}

Stream water temperature is a measure of the concentration of heat energy in the water, and is governed by a combination of external (meteorological conditions including solar radiation, air temperature, wind, humidity, and cloud cover) and internal (discharge, groundwatersurface water exchange, substrate composition, riparian cover, channel width and depth) drivers [22]. The observed daily periodicity in water temperature at both the upstream and downstream sites is in response to natural daily fluctuations in solar radiation and air temperature (Fig. 1) $[23,24]$. The seasonal temperature pattern is driven by the seasonal cycle of incoming solar radiation and day-length. Higher air temperatures and greater solar radiation for longer amounts of time yield higher water temperatures. Therefore, for the period of record, the stream temperatures were highest during the summer months and during the hottest parts of the day (1:30 - 4 PM) and lowest during the fall months and coolest parts of the day (5:30 - $7 \mathrm{AM})$.

The observed differences in water temperature between the downstream and upstream sites and among the courses are attributed to differences in the internal, not external, drivers. The five courses are in close proximity (within 25 miles) of each other and were exposed to similar external meteorological conditions.

The elevated downstream day temperatures, depressed night temperatures, and increased diurnal temperature vari- ability observed below each golf course are attributed to the lack of canopy cover along the golf course reach. The reaches upstream of the golf courses had extensive canopy cover ( $>50 \%)$ while large sections of the golf course reaches were devoid of any vegetated buffer on one or both sides and as such were fully exposed. Canopy cover provides shade, blocks solar radiation, and helps insulate a stream from the heat of the day and the cold of the night [25-40]. It is common practice at golf courses to remove and routinely cut the vegetated buffer along the stream's riparian zone. Full exposure of the stream's surface to direct solar radiation will lead to warmer stream temperatures (Figs. 2 and 3) and greater diurnal temperature variability (Fig. 5). At night, the lack of insulation from the canopy causes the golf course reaches to cool off more readily (Fig. 3). Collectively, the impacts associated with the lack of canopy cover will be most pronounced during the peak solar hours (early - mid-afternoon) and summer months and explain the observed diurnal and seasonal pattern in the downstream minus upstream temperatures (Figs. $\mathbf{2}$ and $\mathbf{3}$ ).

Although other internal drivers besides the extent of riparian cover (i.e., discharge, groundwater-surface water exchange, substrate composition, and channel width and depth) can cause water temperature to vary along a stream reach [22], a comparative look at the characteristics of these drivers between the upstream and in course reaches at each course found them to be quite similar. 

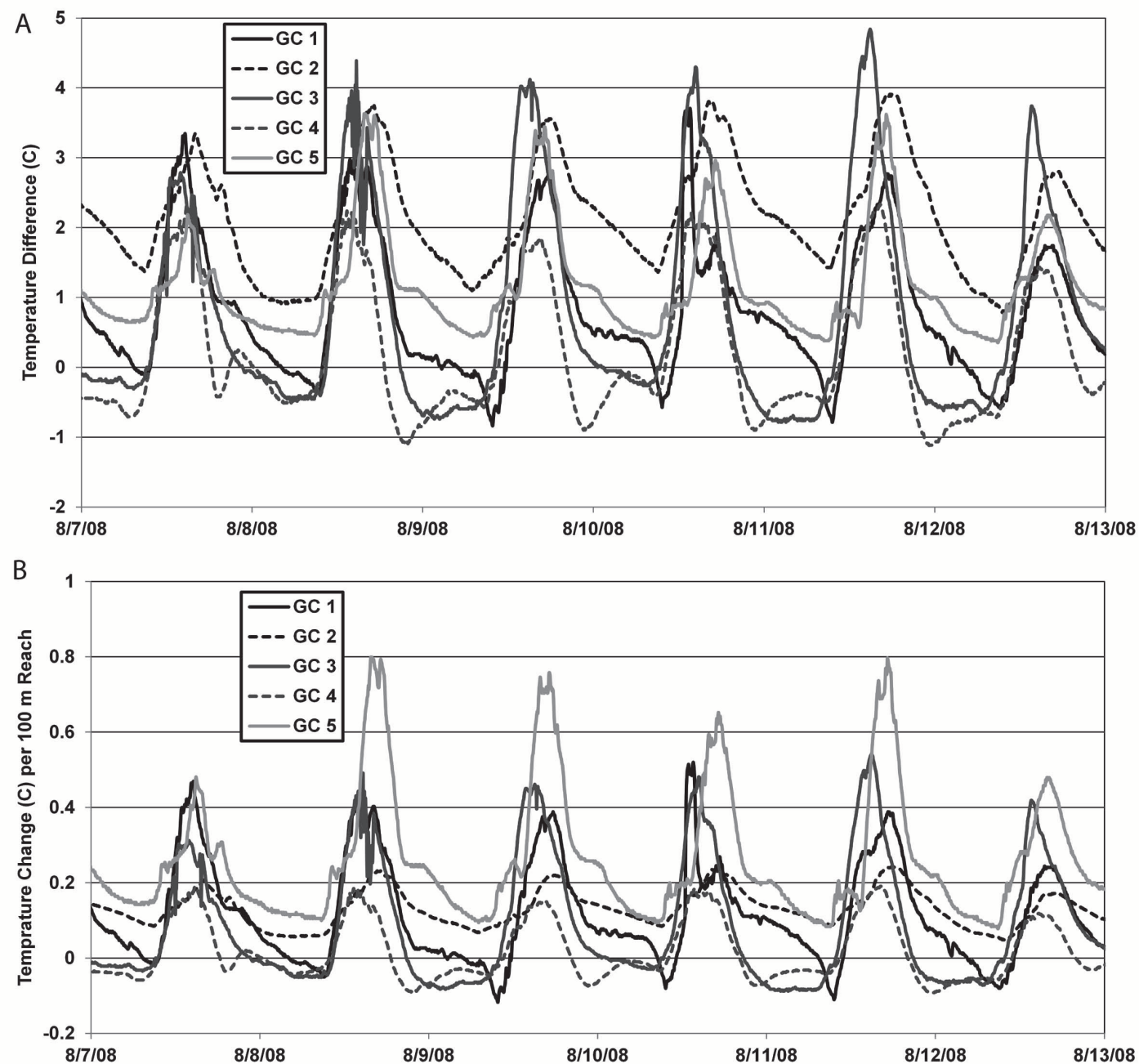

Fig. (3). A) Subset of the data showing the water temperature difference between the downstream and upstream monitoring locations. B) Subset of the data showing the water temperature difference per 100 meters of golf course reach between the downstream and upstream monitoring locations.

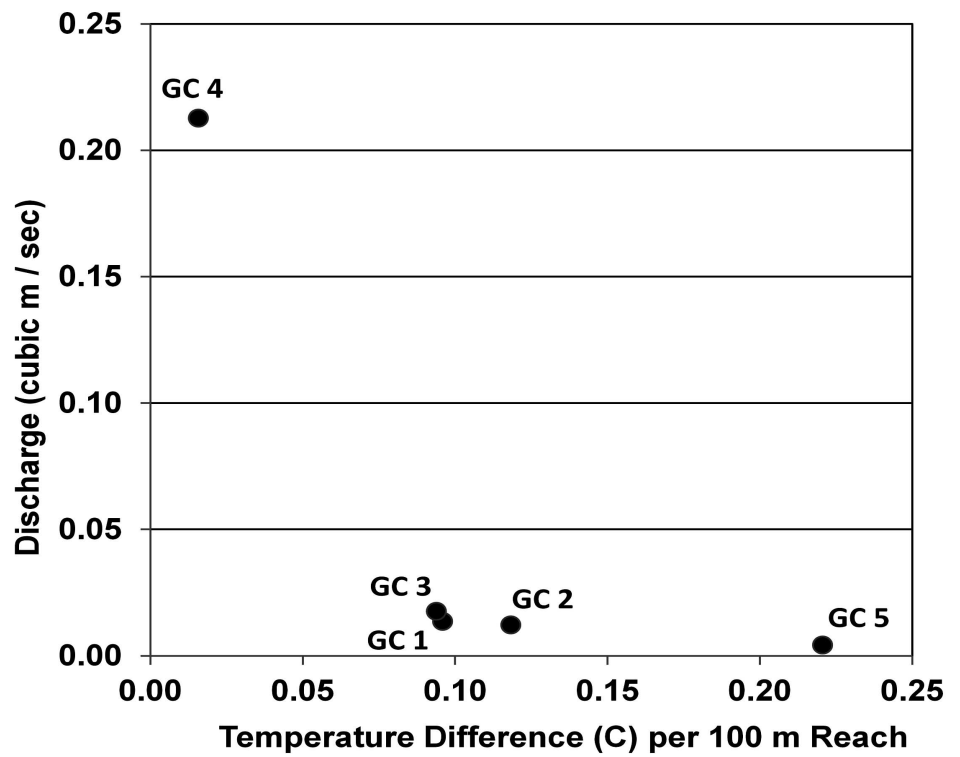

Fig. (4). Plot of the measured discharge in August 2008 at the downstream location of each course verses the average water temperature difference per 100 meters of golf course reach between the downstream and upstream monitoring locations for the month of August. 




Fig. (5). Average diurnal temperature variability at the upstream and downstream monitoring locations.

A stream's discharge will largely dictate its ability to store and release heat energy. The larger the discharge, the more time and energy it will take to heat or cool a water body. As such, any sizable change to the volumetric flow in the stream as it travels through the golf course (withdrawals or changes in groundwater - surface water interactions) will affect its thermal capacity and thus its temperature. Golf courses commonly withdraw water from streams that pass through their grounds to irrigate the turf. The withdrawals reduce flow and, in the process, reduce the thermal buffering capacity of the stream and cause the temperature to increase, but none of the five courses assessed in this study remove water directly from the stream for turf irrigation. Each course has a separate, isolated pond reservoir on site designated for this purpose.

Channel morphology [22, 38, 41-43] and substrate [40] can also impact stream temperature. Increased complexity and heterogeneity in channel pattern, streambed topography, and bottom substrate can produce spatial variations in stream temperature [22], but field inspection of the upstream and in course reaches found similar morphologies with similar widths, depths, and bottom substrate composition within each course. There was no visual field evidence to suggest that channel morphology, substrate composition, or differences in discharge were primarily responsible for the observed temperature changes downstream at any of the courses.

In contrast, the difference in the magnitude of the observed change in stream temperature among the courses was largely due to differences in the stream discharge among the sites. The external drivers along with the presence or lack of riparian cover will dictate the heat load applied to the stream surface, but the discharge will largely govern the magnitude of the temperature response. Streams with larger discharge (GC 4) will be less impacted by the lack of riparian cover relative to those with smaller discharge (GC 5) (Fig. 4). Small streams passing through golf courses with no riparian cover will thus be particularly vulnerable to temperature changes.

The significance of the observed differences in downstream temperature and downstream temperature variability on the stream's biological functioning and biodiversity is unknown, but likely to be important. Temperature is one of the most important environmental parameters regulating stream ecosystems [21]. It exerts a strong influence on many physical and chemical characteristics of water and is one of the primary underlying variables driving or constraining a range of biotic and abiotic processes in streams [44]. Fluctuations in water temperature can induce behavioral and physiological responses in aquatic organisms, and permanent shifts in stream temperature regimes can render formerly suitable habitat unusable for native species [22]. Cold freshwater fish depend on consistently cool stream temperatures for sustained habitat and survival. $26^{\circ} \mathrm{C}$ is typically considered the threshold temperature above which stream temperatures become detrimental, and above $30^{\circ} \mathrm{C}$ often lethal, for many cold freshwater fish species [3]. As water temperature reaches into the upper $20^{\circ} \mathrm{Cs}$, dissolved oxygen levels decline and many forms of aquatic life enter into a condition of stress [3]. Upstream of the golf courses, for the period of study, the $26^{\circ} \mathrm{C}$ threshold was reached never at one site (GC 3 ), occasionally at three of the sites (GC 1,2, and 5), and frequently at the other site (GC 4) during the summer months, but never at any of the upstream sites was the $30^{\circ} \mathrm{C}$ lethal limit breached (Fig. 1). In contrast, downstream of the courses, the $26^{\circ} \mathrm{C}$ threshold was routinely exceeded at all five sites, and the $30^{\circ} \mathrm{C}$ limit exceeded repeatedly at three sites (GC 1, 2, and 4) (Fig. 1). The changes in downstream temperature on account of the golf courses appear large enough to stress, and in some cases kill, species within the aquatic community. In addition, aquatic species are not only sensitive to threshold temperatures, but also sensitive to changes in the temperature variability [20]. The golf courses increased the average diurnal variability at all five sites by as 
much as $4^{\circ} \mathrm{C}$ (Fig. 4). These impacts are potentially large enough to alter the downstream community composition [4547].

\section{CONCLUSIONS}

Although golf courses often serve as green space in an otherwise urban or suburban environment, the results from this study have shown that they can significantly alter the water temperature of streams that pass through their grounds. The comparative analysis of stream water temperature at the five different golf courses showed that the lack of riparian cover along the golf course reaches elevated downstream temperatures by as much as $3-4{ }^{\circ} \mathrm{C}$ during the afternoon hours in the summer and increased the downstream average diurnal temperature variability by as much as $4{ }^{\circ} \mathrm{C}$ within a month. The magnitude of the temperature differences among the courses was largely a function of stream discharge, with smaller streams significantly more impacted. Although the ecological effects of such changes are unknown at these specific sites, the magnitude of the changes is large enough to potentially be detrimental to the stream's aquatic community. The results suggest that golf courses should make concerted efforts to establish and maintain vegetated riparian buffers that would shade the stream and in the process help protect the aquatic ecosystem. In addition to helping mitigate changes to stream temperature, these buffers would presumably provide habitat and corridors for various terrestrial and aquatic species and would help filter and reduce the nutrient loads delivered to the streams from course runoff.

\section{CONFLICT OF INTEREST}

None declared.

\section{ACKNOWLEDGEMENTS}

This research is a contribution of the River Basins Research Initiative at Furman University. Funding was provided by a NSF Research Experiences for Undergraduates (REU) grant (REU Grant \#EAR-0453205).

\section{REFERENCES}

[1] Saito O. Measuring the lifecycle carbon footprint of a golf course and greening the golf industry in Japan. Proceedings in the 4th International Conference on Sustainability Engineering and Science, Auckland, NZ, Nov 30 - Dec 3, 2010.

[2] Balogh JC, Walker WJ, Eds. Golf Course Management and Construction: Environmental Issues. Ann Arbor, MI: Lewis Publishers 1992.

[3] Klein RD. Protecting the Aquatic Environment from the Effects of Golf Courses. Maryland: Community and Environmental Defense Associates 1999.

[4] Beard J. Turf Management for Golf Courses. Chelsea, MI: Ann Arbor Press 2000.

[5] Brown KW, Thomas JC, Duble RL. Nitrogen source effect on nitrate and ammonium leaching and runoff losses from greens. Agron J 1982; 74: 947-50.

[6] Cohen SZ, Nickerson S, Maxey R, Dupuy A, Senita JA. A ground water monitoring study for pesticides and nitrates associated with golf courses on Cape Cod. Ground Water Monit Rev 1990; 10(1): 160-73.

[7] Horsley SW, Moser JA. Monitoring ground water for pesticides at a golf course - a case study on Cape Cod, Massachusetts. Ground Water Monit Rev 1990; 10(1) 101-108.

[8] Cohen S, Svrjcek A, Durborow T, Barnes NL. Water quality impacts of golf courses. J Environ Qual 1999; 28: 798-809.

[9] Petrovic AM. The fate of nitrogenous fertilizers applied to turfgrass. J Environ Qual 1990; 19: 1-14.
[10] Kunimatsu T, Sudo M, Kawachi T. Loading rates of nutrients discharging from a golf course and a neighboring forested basin. Water Sci Technol 1999; 39(12): 99-107.

[11] Mankin KR. An integrated approach for modeling and managing golf course water quality and ecosystem diversity. Ecol Model 2000; 133(3): 259-67.

[12] King K, Balogh J. Water Quality Impacts Associated with Converting Farmland and Forests to Turfgrass. Trans Am Soc Agric Eng 2001; 44(3): 569-76.

[13] Kohler EA, Poole VL, Reicher ZJ, Turco RF. Nutrient, metal, and pesticide removal during storm and nonstorm events by a constructed wetland on an urban golf course. Ecol Eng 2004; 23(4-5): 285-98.

[14] Winter JG, Dillon PJ. Effects of golf course construction and operation on water chemistry of headwater streams on the Precambrian Shield. Environ Pollut 2005; 133(2): 243-53.

[15] Winter JG, Dillon PJ. Export of nutrients from golf courses on the Precambrian Shield. Environ Pollut 2006; 141(3): 550-4.

[16] Moss J, Bell G, Kizer M, Payton M, Zhang H, Martin D. Reducing nutrient runoff from golf course fairways using grass buffers of multiple heights. Crop Sci 2006; 46: 72-80.

[17] King K, Balogh J, Harmel R. Nutrient flux in storm water runoff and baseflow from managed turf. Environ Pollut 2007; 150(3): 321-8.

[18] King K, Balogh J, Hughes K, Harmel R. Nutrient load generated by storm event runoff from a golf course watershed. J Environ Qual 2007; 36(4): 1021-30.

[19] Allan JD. Stream ecology: structure and function of running waters. New York: Chapman and Hall 1995.

[20] Dallas H. Water temperature and riverine ecosystems: An overview of knowledge and approaches for assessing biotic responses, with special reference to South Africa. Water S A 2008; 34(3): 393-404.

[21] Hester ET, Doyle MW. Human impacts to river temperature and their effects on biological processes: a quantitative synthesis. J Am Water Resour Assoc 2011; 47(3): 571-87.

[22] Poole B, Berman C. An ecological perspective on in-stream temperature: Natural heat dynamics and mechanisms of human-caused thermal degradation. Environ Manage 2001; 27(6): 787-802.

[23] Stoneman CL, Michael LJ. A simple method to classify stream thermal stability with single observations of daily maximum water and air temperature. North Am J Fish Manag 1996; 16: 728-37.

[24] Webb BW, Zhang Y. Spatial and seasonal variability in the components of the river heat budget. Hydrol Process 1997; 11: 79-101.

[25] Brown GW, Krygier JT. Effects of clear-cutting on stream temperature. Water Resour Res 1970; 6: 1133-9.

[26] Hewlett JD, Fortson JC. Stream temperature under an inadequate buffer strip in the southeast Piedmont. Water Resour Bull Water Res Assoc 1982; 18: 983-88.

[27] Theurer FD, Lines I, Nelson T. Interaction between riparian vegetation, water temperature, and salmonid habitat in the Tucannon River. Water Resour Bull Water Res Assoc 1985; 21: 53-64.

[28] Salo EO, Cundy TW. Eds. Streamside management: Forestry and fishery interactions. College of Forest Resources, University of Washington, Seattle, WA 1987.

[29] Beschta RL, Taylor RL. Stream temperature increases and land use in a forested Oregon watershed. Water Resour Bull 1988; 24: 1925.

[30] Holtby LB. Effects of logging on stream temperatures in Carnation Creek, British Columbia, and associated impacts on the coho salmon (Oncorhynchus kisutch). Can J Fish Aquat Sci 1988; 45: $502-15$.

[31] Hostetler SW. Analysis and modeling of long-term stream temperatures on the Steamboat Creek Basin, Oregon: Implications for land use and fish habitat. Water Resour Bull 1991; 27: 637-48.

[32] Naiman RJ. Ed. Watershed management: Balancing sustainability and environmental change. New York: Springer Verlag 1992.

[33] Li HW, Lamberti GA, Pearsons TN, Tait CK, Buckhouse JC. Cumulative effects of riparian disturbances along high desert trout streams of the John Day Basin, Oregon. Trans Am Fish Soc 1994; 123: 627-40.

[34] Davies PE, Nelson M. Relationships between riparian buffer widths and the effects of logging on stream habitat, invertebrate community composition and fish abundance. Aust J Mar Freshwat Res 1994; 45: 1289-305.

[35] National Research Council. Upstream: Salmon and society in the Pacific Northwest. Washington DC: National Academy Press 1996. 
[36] Larson LL, Larson SL. Riparian shade and stream temperature: a perspective. Rangelands 1996; 18: 149-52.

[37] Beschta RL. Riparian shade and stream temperature: An alternative perspective. Rangelands 1997; 19: 25-8.

[38] Zwieniecki MA, Newton M. Influence of streamside cover and stream features on temperature trends in forested stream of western Oregon. West J Appl Forest 1999; 14: 106-13.

[39] Johnson SL, Jones JA. Stream temperature responses to forest harvest and debris flows in western Cascades, Oregon. Can J Fish Aquat Sci 2000; 57 (Suppl 2): 30-9.

[40] Johnson SL. Factors influencing stream temperatures in small streams: Substrate effects and a shading experiment. Can J Fish Aquat Sci 2004; 61: 913-23.

[41] Hawkins CP, Hogue JN, Decker LM, Feminella JW. Channel morphology, water temperature, and assemblage structure of stream insects. J North Am Benthol Soc 1997; 16: 728-49.
[42] Beschta RL, Platts WS. Morphological features of small streams: Significance and function. Water Resour Bull 1986; 22: 369-77.

[43] Evans EC, Petts GE. Hyporheic temperature patterns within riffles. Hydrol Sci 1997; 42: 199-213.

[44] Nelson KC, Palmer M.A. Stream temperature surges under urbanization and climate change: Data, models, and responses. J Am Water Resour Assoc 2007; 43(2): 440-52.

[45] Crisp DT, Mann RHK, Cubby PR. Effects of regulation of the River Tees upon fish populations below Cow Green Reservoir. J Appl Ecol 1983; 20: 371-86.

[46] Harding JS. Physico-chemical parameters and invertebrate faunas of three lake inflows and outlets in Westland, New Zealand. N Z J Mar Freshwat Res 1992; 26: 95-102.

[47] Vinson MR. Long-term dynamics of an invertebrate assemblage downstream from a large dam. Ecol Appl 2001; 11(3): 711-30.

Received: March 28, 2012

Revised: May 22, 2012

Accepted: May 23, 2012

(C) Dripps et al: Licensee Bentham Open.

This is an open access article licensed under the terms of the Creative Commons Attribution Non-Commercial License (http://creativecommons.org/licenses/ by-nc/3.0/) which permits unrestricted, non-commercial use, distribution and reproduction in any medium, provided the work is properly cited. 